\title{
IMPLEMENTASI SKILL MELIPAT, MENARIK GARIS DAN MENUANG BIJI DAPAT MENINGKATKAN MOTORIK HALUS ANAK USIA DINI DI RA DEWI MASYITHOH MUSLIMAT NU KECAMATAN PUGER KAB. JEMBER
}

\author{
Lilik Widayati' Samsul Hidayat' Makmuri \\ PASCA SARJANA IKIP PGRI JEMBER \\ lilikwidiyawati5@gmail.com
}

\begin{abstract}
Motor improvement must be a top priority in early childhood learning both through the skill of folding, drawing lines and pouring seeds can improve fine motor skills in early childhood. this all requires learning design both in the planning, implementation and evaluation components. The purpose of this study was to describe the implementation of the skill of folding, drawing lines and pouring seeds to improve fine motor early childhood at RA Dewi Masyithoh Muslimat NU, Puger District, Jember Regency. The method used in this study uses a qualitative approach with case studies. Researchers use several data collection techniques, namely (a). In-depth interviews (b). Observation of roles and (c). ocumentation. while the data analysis model uses Milles and Huberman data analysis with validity checks using credibility criteria. These results indicate that (1) Skill planning includes checking work plans on the previous day, making concepts to follow up on previous learning outcomes, determining games to revive learning, and determining learning media. (2) Skill implementation, First applying religious culture in the Second learning process , maximizing the role in teaching, such as inviting children to use media around the school environment, providing stimuli to stimulate children's skills and creativity, and approaching children who have learning difficulties. Third, intersperse learning by singing and playing. Fourth, pay attention to the effectiveness of the use of media and the effectiveness of time, Fifth, to enable parents to learn certain skills. (3) Evaluation of folding skills, evaluation of planning and implementation of skill learning is carried out by the first principal, Control internally through monitoring performance on teachers. Secondly, parental satisfaction control. Evaluations carried out by the teacher are guided by the applicable curriculum, while the evaluation of parents for children at home is by reviewing lessons learned at school.
\end{abstract}

Keywords: Skill improvement, Fine Motorbike

\begin{abstract}
Abstrak : Peningkatan motorik harus menjadi prioritas utama dalam pembelajaran anak usia dini baik melalui skill melipat, menarik garis dan menuang biji dapat meningkatkan motorik halus anak usia dini. hal ini semua membutuhkan desain pembelajaran baik pada komponen perenacanaan, pelaksanaan dan evaluasi. Tujuan penelitian ini adalah Tujuan dari penelitian ini adalah untuk mendeskripsikan Implementasi skill melipat, menarik garis dan menuang biji dalam meningkatkan motorik halus Anak usia dini di RA Dewi Masyithoh Muslimat NU Kecamatan Puger Kabupaten Jember. Metode yang digunakan dalam Penelitian ini menggunakan pendekatan kualitatif dengan junis studi kasus.Peneliti menggunakan beberapa teknik
\end{abstract}


pengumpulan data, yaitu (1).Wawancara mendalam (indepth interview), (2). Pengamatan peran serta dan (3). dokumentasi.sedangkan Model analisis data menggunakan analisis data Milles dan Huberman dengan pengecekan keabsahan menggunakan kriteria kredibilitas. Hasil ini menunjukkan bahwa (a) Perencaan skill diantaranya mengkroscek perencanaan kerja pada hari sebelumnya,membuat konsep untuk hasil belajar sebelumnya,menentukan permainan untuk menghidupkan pembelajaran, dan menentukan media pembelajaran,(b) Pelaksanaan skill, Pertama penerapan kultur keagamaan dalam proses pembelajaran Kedua, memaksimalkan peran dalam mengajar, seperti mengajak anak untuk menggunakan media-media yang ada disekitar lingkungan sekolah, memberikan stimulus untuk memacu skill dan kreatifitas anak, dan melakukan pendekatan kepada anak yang mengalami kesulitan belajar. Ketiga, menyelingi pembelajaran dengan bernyanyi dan bermain. Keempat, memperhatikan efektifitas penggunaan media dan efektifitas waktu, Kelima, menfungsikan orang tua dalam pembelajaran skill tertentu,(c) Evaluasi skill melipat, evaluasi terhadap perencanan dan pelaksanaan pembelajaran skill dilakukan kepala sekolah pertama, Kontrol secara internal melalui pengawasan kinerja pada guru-guru. Kedua, kontrol kepuasan orang tua. Evaluasi yang dilakukan oleh guru berpedoman pada kurikulum yang berlaku, sedangkan evaluasi orang tua tua kepada anak di rumah adalah dengan mereview pembelajaran yang sudah dididapatkan di sekolah.

Kata Kunci : Peningkatan skill, Motorik Halus

\section{PENDAHULUAN}

Pendidikan anak didalam keluarga merupakan hal yang sangat fundamental dalam proses sosialisasi dan internalisasi primer. Biasanya pembinaan belajar awal anak dimulai sejak usia 0-6 tahun yang disebut pendidikan anak usia dini (PAUD), tentu dengan mempehatikan perkembangan dan potensi anak. PAUD dalam pendidikannya dilakukan melalui tiga jalur yaitu jalur formal meliputi Taman Kanak-kanak (TK), RA, atau bentuk lain yang sederajat, jalur non formal meliputi Kelompok Bermain (KB), TPA, dan bentuk lain yang sederajat serta dan jalur informal yang diselenggarakan di dalam lingkungan keluarga (Yuliani, 2009: 8).

Secara umum, penyelenggaraan PAUD memiliki tujuan mengembangkan seluruh potensi yang dimiliki anak dengan sebuah pendekatan paedagogik yaitu belajar sambil bermain sehingga anak akan belajar secara menyenangkan. Menurut Docket dan Fleer (Yuliani, 2009: 87) bermain merupakan usia anak, karena mereka senang-senangnya bermain maka disaat itu pula anak akan menginstalasi pengetahuan sekaligus mengembangkan potensinya.

Pengetahuan lebih bermakna dan mudah dipahami apabila disampaikan dengan model bermain. Setiap yang Anak lahir membawa berbagai fitrah dan kecerdasan. Pendidik perlu menggali setiap fitrah anak dengan memfasilitasinya agar berkembangan potensi tersebut berjalan optimal sesuai dengan tahapan-tahapannya. ada beberapa pembelajaran yang cukup urgen untuk dikembangkan diantaranya nilai agama, moral, sosial emosional, kognitif, bahasa dan fisik motorik (Ramli, 2005: 185). Pendidik harus memperhatikan setiap perkembangan aspekaspek yang ada agar anak dapat terampil pada bakat dan minatnya sendiri seperti aspek fisik motoric yang berpengaruh besar dalam belajar anak.

Slamet dan Suyanto secara khusus menyampaikan bahwa pemebejaran dengan bermain dapat mengembangkan potensi Bahasa dan Kemampuan social setiap manusia. Anal disaat bermain akan menggunakan bahasa, baik untuk berkomunikasi bersama temannya maupun menyampaikan isi pikirannya (thinking alound). 
Anak di saat bermain juga berinteraksi dengan yang lain. Interaksi tersebut mengajarkan anak cara memberi dan menerima, menolak atau setuju dengan ide dan perilaku anak lain (Slamet dan Suyanto,2005:119-121).

Hurlock mengatakan dalam proses pembelajaran, bermain ada hal yang mempengaruhinya misalnya aspek Healthy, seorang anak yang sehat mayoritas energinya digunakan untuk bermain aktif terutama permainan olah raga sebaliknya anak yang kekurangan tenaga lebih suka pada hiburan. Motoric Skill Development. koordinasi motorik setiap usia anak dipengaruhi oleh tingkat permainan dirinya. Anak akan melakukan apa saja serta waktu bermiannya dipengaruhi oleh perkembangan motorik mereka. kondali motorik anak yang baik berpotensi pada permainan-permainan aktif. Intellegense. Kepandaian anak dan yang kurang bisa dilihat pada tingkat kecerdikan mereka dalam bermain dan mereka menunjukkan keaktifan yang luar biasa.

Semakin bertambah usianya, mereka akan lebih menunjukan respon terhadap pola permainan kecerdasan, membaca, konstruksi dan dramatik. Anak yang pandai dapat menyeimbangkan faktor fisik dan intelektual serta dapat menunjukkan keseimbangan perhatian bermain yang lebih besar (Slamet dan Suyanto,2005:43-44).Gender Side. Permainan Anak laki-laki lebih kasar ketimbang anak perempuan. Anak laki-laki lebih suka permainan dan olahraga daripada permainan jenis lain. Anak laki-laki pada awal masa kanak-kanak memiliki perhatian pada berbagai jenis permainan dari pada anak perempuan, namun sebaliknya terjadi pada akhir masa kanak-kanak. Child's Environtment. Anak yang berada pada lingkungan pedesaan dan perkotaan memiliki daya bermain yang berbeda.anak desa cendrung kurang bermain sedangkan anak kota lebih banyak bermain hal ini karena pengaruh kurangnya teman bermain serta kurangnya failitas permainan dan waktu bebas. Economic-Social Status. Strata ekonomi orang tua anak berpengaruh pada tingkat permainnan anak, bagi anak yang orang tuanya memiliki status sosial ekonomi yang lebih tinggi anaknya menyukai kegiatan-kegiatan yang mahal, seperti lomba atletik dan sepatu roda, sebaliknya Anaka dari keluarga sosial ekonomi kebawah cendrung bermain dengan peralatan apa adanya seperti bermain bola dan renang.

Strata social juga dapat mempengaruhi bacaan dan tontonan anak, jenis kelompok rekreasi yang dimilikinya dan supervisi terhadap mereka. Sphare Quantity. Volume waktu bermain terutama tergantung kepada status ekonomi keluarga. Apabila tugas rumah tangga atau pekerjaan menghabiskan waktu luang mereka, anak terlalu lelah untuk melakukan kegiatan yang membutuhkan tenaga yang besar. Playing Tolls fasilitas permainanpun juga mempengaruhi dirinya. Misalnya, boneka dan binatang buatan mendukung permainan purapura; banyaknya balok, kayu, cat air, dan lilin dapat mendukung permainan yang sifatnya konstruktif. (Hurlock, 1997:327).

Hurlock (Lismadiana, 2013: 105) menyampaikan bahwa perkembangan motorik merupakan perkembangan kendali motorik jasmani melalui kegiatan pusat syaraf, urat syaraf dan otot yang terkoordinasi. Ada dua perkembangan motoric anak yaitu keterampilan motorik kasar dan keterampilan motorik halus (Santrock, 2007: 210-219). Bagi anak dengan usia 4-5 tahun mereka berkembang aspek motorik kasarnya, namun setelah usia 5 tahun baru terjadi perkembangan motorik halus. Kemampuan motorik halus adalah komponen yang mensupport bagi perkembangan kognitif, kemampuan sosial dan emosional anak. Perkembangan-perkembangan tersebut akan berjalan optimal bila tahapan-tahapan perkemabangan motorik tersebut dilakukan dengan pola-pola yang benar. Begitupula kecerdasan sosial dan emosional anak dapat dilatih melalui kegiatan bermain sehingga pengalaman bermain akan membuat pengetahuan anak akan terus berkembang (Sumantri, 2005: 144-145). Oleh sebab itu pembelajaran yang variatif akan menarikm perhatian anak. 
Menurut Andang Ismail (2006: 230-234), Permainan seperti balok, menggambar, menggunting, menempel, mewarnai gambar, membentuk, dan menggambar dengan jari dapat mengembangkan kemampuan kreatif anak. Sedangkan menurut Sumatri (2005 : 151-152) permaina seperti meronce, melipat, menggunting, mengikat, membentuk, menulis awal, dan menyusun mengembangkan kemampuan kreatif anak.

Keterampilan motorik halus anak akan terus dipraktekkan dalam kehidupan sehari-harinya seperti merekatkan tas atau sepatu, meresleting tas, mengancingkan baju, mengikat tali sepatu, dan lain-lain. Skill motorik halus dapat didorong secara terus menerus melalui pembiasaan yang akan digunakan anak sepanjang hidupnya. Sehingga peneliti akan menerapakan kegiatan keterampilan motorik halus anak pada kegiatan sehari-hari meliputi kegiatan meresletingkan tas, mengancingkan baju dan mengikat tali sepatu.

Dalam Uraian tentang keterampilan motorik halus pada saat kegiatan sehari-hari anak senada dengan pendapat Bredekamp dan Copple (Ramli, 2005: 191-192) tentang perkembangan motorik halus bahwa pada anak usia 5-6 tahun anak telah mampu melakukan kegiatan membuka reseliting mantel, memasang kancing dengan baik, mengikat sepatu dengan bantuan orang dewasa, dan berpakaian dengan cepat. Kegiatan tersebut dilakukan pasca anak mendapat perlakuan dari kegiatan yang melibatkan penggunaan serta pengontrolan gerakan otot-otot kecil pada jari-jemari tangan. Bagi Anak yang memiliki keterampilan motorik halusnya baik akan mampu melakukan kegiatan keterampilan motorik halus dalam kehidupan sehari-hari dengan baik dan lancar.

Salah satu kegiatan yang dapat mengembangkan keterampilan motorik halus anak yaitu kegiatan membentuk. Kegiatan membentuk dapat menggunakan berbagai media seperti tanah liat, plastisin, dan bubur koran/kertas. Aktivitas membentuk sangat digemari anak dan membentuk termasuk juga dalam kategori pengembangan kreativitas yang menuntut daya imajinasi. Aktivitas membentuk dapat dilakukan melalui bermain clay. Kegiatan clay sering dilakukan karena mudah dan sederhana untuk anak.

Bermain clay meliputi beberapa jenis menurut Indira (diantaranya yaitu paper clay (bubur kertas), lilin malam (color clay),polymer clay, plastisin clay (clay tepung) dan clay asli (tanah liat) Lanjarsari Endah Estu, 2013 : 29-31).

Kegiatan membentuk dengan bermain clay tersebut sesuai dengan standar tingkat pencapaian perkembangan yang diatur dalam Permendiknas Nomor 58 Tahun 2009 karena kurikulum yang digunakan masih kurikulum 2010 belum menggunakan Permendiknas Nomor 137 Tahun 2014. Standar Tingkat Pencapaian Perkembangan berisi kaidah pertumbuhan dan perkembangan anak usia dini sejak lahir sampai dengan usia enam tahun oleh Ika Budi Maryatun (Modul Pengembangan Kurikulum, 2012).

Clay adalah semacam bahan yang menyerupai lilin, lembut, mudah dibentuk, dapat mengeras, mengering dengan sendirinya. Jenis clay yang digunakan dalam penelitian ini adalah paper clay disebut juga dengan bubur kertas. Bubur kertas adalah bahan yang mudah dibentuk terbuat dari kertas bekas seperti koran, kardus dan jenis kertas lainnya.

Jenis-jenis permainan dan beberapa aktivitas tersebut pada Tingkat pencapaian perkembangan anak, dapat menggambarkan pertumbuhan dan perkembangan yang diharapkan dicapai anak pada rentang usia tertentu. Misalnya pada Anak TK kelompok B seharusnya sudah mampu melakukan eksplorasi dengan berbagai media salah satunya dapat melalui membentuk sesuatu dari bubur kertas. Sehingga, anak yang telah mampu mencapai standar tersebut berarti dapat berlanjut ke tingkat perkembangan yang selanjutnya. 
Khususnya untuk motorik halus dibutuhkan perhatian yang cukup tinggi agar setiap proses yang dilalui anak dapat dicapai sesuai tingkat perkembangan yang maksimal. Para pendidik memiliki peran sentral sebagai motivator, fasilitator, mentor/penasehat yang dapat membantu anak dalam mengembangkan potensi dan minat pada bidang yang digemarinya. Penguasaan keterampilan motorik juga dapat memacu anak untuk menekuni bidang tertentu sejak dini seperti bermain melukis, musik, membuat kerajinan, membuat gambar desain, dan lain sebagainya.

Permainan dan aktivitas anak berpengaruh besar pada pola perkembangan potens-potensinya. Berdasar hasil penelitian yang dilakukan oleh Sopiawati (2014) dengan judul "Meningkatkan Kemampuan Motorik Halus Anak Taman Kanak-Kanak Melalui Bermain Tanah Liat di Kelompok B TK PGRI Kecamatan Lembang-Bandung. Hasil penelitian ini menunjukkan bahwa pada penggunaan tanah liat (clay) dalam pembelajaran dapat meningkatkan kemampuan motorik halus anak lebih baik. Kemampuan motorik halus anak kelompok B TK PGRI berkembang meningkat menjadi 26\%, sedangkan bagi anak yang berkembang sangat baik meningkat sebesar $76 \%$. Sehingga penelitian ini berkesimpulan bahwa bermain clay dapat meningkatkan keterampilan motorik anak.

Beberapa penelitian terus dilakukan baik pada fokus hasil pembelajaran maupun pada proses-proses administratif dan edukatif guru, baik pada tahap perencanaan, pelaksanaan dan evaluasi. Misalnya hasil pengamatan awal pada tanggal 25 sampai dengan tanggal 28 Februari 2018 yang dilakukan di RA Dewi Masyithoh Muslimat NU Kecamatan Puger Kabupaten Jember bahwa media pembelajaran untuk meningkatkan motorik halus menggunakan plastisin untuk menciptakan sebuah bentuk dan majalah TK untuk mengisi kegiatan pembelajaran setiap harinya. Pada salah satu kegiatan yaitu mengayam, gerakan tangan anak sudah terlihat baik sehingga sudah mampu membuat anyaman yang rapi sesuai petunjuk guru.

Kegiatan lain Pada hari Kamis 1 Maret 2018 yaitu mencocokkan. Terlihat Anak sudah mampu merobek hasil cocokan sehingga anak kreatif dengan menggunakan alat cocok untuk membantu merobek gambar. Peneliti melaksanakan kegiatan pra penilitian dengan media kertas yang menunjukkan bahwa keterampilan motorik halus anak kelompok B di RA Dewi Masyithoh Muslimat NU Kecamatan Puger sudah cukup baik. Hal tersebut karena stimulasi yang diberikan guru pada proses pembelajaran setiap harinya cukup optimal yakni dengan majalah dan Lembar Kerja Anak serta media yang digunakan bervariasi. Gerakan tangan anak dalam melakukan gerakan rumit yang melibatkan otot-otot kecil berkembang secara maksimal.

Dari gambaran di atas peneliti merasa penting untuk melakukan eksplorasi lebih mendalam secara deskriptif pada keterampilan motorik halus anak melalui kegiatan bermain kertas di RA Dewi Masyithoh Muslimat NU Kecamatan Puger. Bermain bubur kertas ini dapat menjadi inovasi media pembelajaran yang berbeda untuk anak belajar. Bahkan dapat menghasilkan model-model terbaru yang inovatif.

Kegiatan pembelajaran RA Dewi Masyithoh Muslimat NU Kecamatan Puger Kabupaten Jember didesain oleh guru dengan menggunakan berbagai pendekatan, media dan sarana prasarana pembelajaran lainnya. Guru menjadi kunci dalam pembelajaran baik dari awal perencanaan, pelaksanaan, dan evaluasinya. Kegiatan tersebut berada dalam rangkaian kurikulum, dengan demian guru harus mampu melakukan pengembangan-pengembangan kurikulum anak usia dini dengan memperhatikan pertama,pembelajaran harus terfokus pada keseluruhan perkembangan skill anak dan dibuat secara terprogram dengan mengintegrasikan semua bidang pengembangan, kedua, guru sebagai pengembang pembelajaran memiliki pemahaman yang memadai tentang teori perkembangan 
dan belajar, ketiga, anak adalah peserta didik aktif sehingga pendekatan yang paling tepat dalam pembelajaran anak usia dini adalah kegaiatan bermain dan keempat, pembelajaran harus merefleksikan peran situasi dan kondisi sosial dan budaya yang berkembang sesuai dengan tahapan perkembangan anak, (Yuliani dan Bambang,2010 : 17).

Peneliti akan mengeksplorasi keterampilan motorik halus keterampilan melipat, menarik garis dan menuang biji. Penggunaan media yang berbeda yaitu media melipat, menarik garis dan menuang biji yang dapat menjadi keterampilan baru bagi anak. Anak dapat mengetahui proses pembuatan media baik sebelum digunakan maupun cara menggunakannya. Pendidik dapat melibatkan anak secara langsung dalam proses pembelajaran seperti mengenalkan bahan dan alat yang akan digunakan. Anak akan lebih tertarik dan antusias karena penggunakan media pembelajaran yang berbeda. Pemilihan media kertas dan biji-bijian karena bahannya banyak ditemukan di lingkungan dan merupakan pemanfaatan dari bahan bekas bahkan bisa diambil dimana anak tinggal dalam kesehariannya yaitu lingkungan alam sekitar anak.

Penelitian ini juga memiliki alasan yang lain bahwa anak dapat bereksplorasi membuat bentuk yang sesuai keinginannya, anak akan merasa senang bila media belajar yang digunakan bervariasi. Selain itu permainan menggunakan kertas dan biji-bijian dapat melatih otot-otot kecil tangan serta koordinasi mata dan tangan. Anak dapat belajar untuk tekun, bersabar, berimajinasi saat bermain bubur kertas ini. Dengan demikian, penelitian ini berjudul Implementasi Model Pembelajaran Learning By Playing Untuk Meningkatkan Motorik Halus Anak Usia Dini (Studi kasus di RA Dewi Masyithoh Muslimat NU kecamatan Puger KAB. Jember). Adapun fokus dalam kajian ini pertama bagaimana perencanaan,pelaksanaan dan evaluasi model Learning By Playing dalam dalam meningkatkan motorik halus Anak usia dini di RA Dewi Masyithoh Muslimat NU Kecamatan Puger Kabupaten Jember, dengan tujuan penelitian untuk mendeskripsikan Implementasi Model Pembelajaran Learning By Playing dalam Meningkatkan Motorik Halus Anak Usia Dini (Studi kasus di RA Dewi Masyithoh Muslimat NU kecamatan Puger KAB. Jember).

\section{METODE}

Fenomena penelitian ini akan menangkap makna sebuah tindakan dalam proses pembelajaran maka pendekatan yang cocok dalam penelitian ini menggunakan pendekatan kualitatif dengan jenis studi kasus yang bertujuan untuk mendiskripsikan penerapan keterampilan melipat, menarik garis dan menuang biji dapat meningkatkan motorik halus anak usia dini yang merupakan fenomena perilaku sosial (social action) yakni hubungan dalam pembelajaran (Didaktik-metodik) antara guru dan peserta didiknya. Sehingga dalam hal ini peneliti memahami proses tersebut dengan menggunakan cara pandang persepsi emik,yang menurut Moleong adalah suatu pendekatan yang digunakan untuk memahami sebuah peristiwa berdasarkan sudut pandang subjek penelitian yaitu orang yang diteliti, bukan peneliti,(Moleong, $2006: 83$ ).

Penelitian ini bertujuan untuk memahami perilaku atau tindakan-tindakan pendidik dalam memenejerial pembelajaran serta siswa selalu objek dan subjek dalam pembelajaran. Berdesarkan hal terebut maka pendekatan yang digunakan fenomenologik naturalistic. (Moleong, 2006 : 58), karena memahami aktor,tempat dan prosesnya secara alamiah.

Lokasi penelitian ini mengambil latar belakang tempat dan masalah didaerah yang jarang menjadi objek kajian penelitian, rata-rata para peneliti banyak mengambil tempat di lokasi penelitian yang dekat dengan pusat 
pemerintahan dan dilembaga-lembaga pendidikan yang sudah unggul baik dalam hal mutu maupun manajemen dan komponen-komponen pendukung lainnya. Namun peneliti mengambil penelitian di Penelitian dilakukan di ruang kelas dan halaman RA Dewi Masyithoh Muslimat NU Puger Jember, disebabkan beberapa hal, diantaranya prestasi lembaga dibandingkan dengan lembaga lainya di kecamatan Puger, walaupun lembaga swasta kinerja guru-gurunya bersaing dengan guru Negeri.

Pada penelitian ini data yang terkumpul berupa data primer dan data sekunder. Data primer berupa hasil wawancara dan observasi. Sedangkan data sekunder adalah data yang dikumpulkan, diolah dan disajikan oleh pihak lain seperti dokumen-dokumen penting.

Untuk pengumpulam data Peneliti menggunakan Wawancara mendalam (indepth interview), Pengamatan peran serta (participant observation), dan . dokumentasi.

Teknik analisis data model Milles dan Huberman dengan tahapan reduksi, penyajian data dan kesimpulan digunakan dalam penelitian ini karena penelitian ini kasus tunggal sehingga analisis data menggunakan analisis kasus individu (individual case).

Pengecekan keabsahan Dalam penelitian ini peneliti menggunakan kriteria kredibilitas. Untuk menjamin kesahihan data, ada tujuh teknik pencapaian kredibilitas data, perpanjangan keikutsertaan, ketekunan pengamatan, trianggulasi, pemeriksaan sejawat melalui diskusi, kecukupan referensial, kajian kasus negatif dan pengecekan anggota.

\section{HASIL DAN PEMBAHASAN}

Penelitian yang dilakukan menghasilkan sebuah model Pembelajaran Learning By Playing dalam hal ini analisis yang menunjukkan bahwa :

Perencanaan skilll melipat, menarik garis dan menuang biji dalam meningkatkan motorik halus anak usia dini. Secara umum perencanaan pembelajaran halaman RA Dewi Masyithoh Muslimat NU Puger Jember dilakukan dengan (1). Mengkroscek perencanaan kerja pada hari sebelumnya, (2). Membuat konsep untuk menindak lanjuti hasil belajar sebelumnya, (3). Menentukan permainan untuk menghidupkan pembelajaran, dan (4). Menentukan media pembelajaran. Keseluruhan langkah-langkah tersebut dilaksanakan dalam forum permusyawarahan antar guru dilembaga yang rutin diaksanakan setiap selesai kegiatan belajar berlangsung atau sebelum jam pelajaran dimulai.

Perencanaan pembelajaran learning by playing juga berbicara penggunaan media dan metode. penggunaan media tersebut, pelaksanaanya dikembangkan dengan metode dan media sendiri yang ada disekitar lingkungan sekolah serta mudah dikenal atau mudah dijangkau oleh anak, seperti media kertas lipat untuk melipat berbagai macam bentuk dan pola-pola tertentu. Biji-bijian dan penggaris plastik. Termasuk salah satu media yang dikembangkan sendiri oleh sekolah adalah pengadaan media LCD proyektor yang terpasang dimasing-masing kelas.

Beberapa hal dalam perencanaan yang perlu menjadi perhatian adalah pemilihan game, peneliti belum menemukan rangkaian game apa saja untuk menunjang kemampuan motorik halus anak. Karena disadari atau tidak, pengaruh permainan terhadap proses belajar anak adalah untuk menghindari kejenuhan pada anak serta 
menjadikan suasana belajar tetap hidup dan menyenangkan. Berbicara terkait learning by playing, tentu juga bicara tentang jenis permainan yang digunakan dalam pembelajaran.

Berdasarkan kajian dilapangan, dapat disimpulkan bahwa ada beberapa prinsip-prinsip dalam menyusun pembelajaran keterampilan motorik pada anak melalui skil melipat kertas, menarik garis dan menuang biji yaitu, mengacu pada hasil perencanaan sebelumnya untuk melihat sejauh mana perkembangan anak, ketepatan dalam pemilihan media, pemilihan permainan utuk mencairkan suasana serta yang paling penting adalah kolektivitas kerja guru untuk terus berkoordinasi pada setiap perannya dalam mensukseskan kegiatan belajar di RA Dewi Masyitoh tersebut. Dari deskripsi di atas maka model Perencanaan skill melipat, menarik garis dan menuang biji dalam meningkatkan motorik halus anak usia dini dapat dilihat pada Gambar.1 dibawah ini :

\section{Gambar.1}

Model Perencanaan Pembelajaran Skill

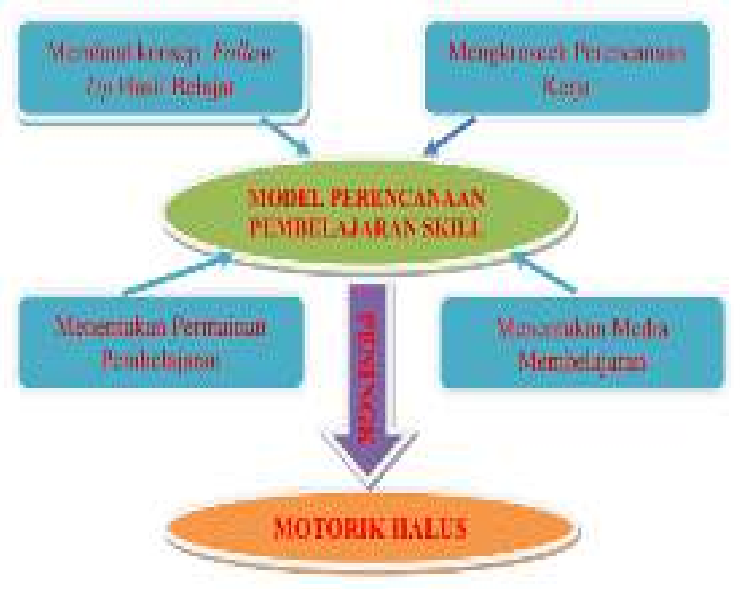

Pelaksanaan skilll melipat, menarik garis dan menuang biji dalam meningkatkan motorik halus anak usia dini. RA Dewi Masyithoh merupakan suatu lembaga yang berkedudukan dibawah naungan Muslimat NU Puger Jember, sehingga kultur keagamaan sangat mewarnai dalam kehidupan sekolah, mulai dari mengawali pembelajaran sampai mengakhiri pembelajaran. RA Dewi Mashitoh berharap kegiatan tersebut mampu membentuk kepribadian anak dengan wawasan Islam ahu sunnah waljamaah sesuai dengan visi misi pada lembaga RA Dewi Mashitoh. Melalui yang diajarkan setiap pagi hari mengawali aktifitas dengan berdoa mengharap ridlo Allah SWT yang maha kuasa, kebisaaan berdoa yang ada disekolah tidak hanya dilakukan di RA Dewi Masyithoh saja, dirumah kebiasaan berdoa juga dilakukan yang memfungsikan orang tua sebagai pengarah. Harapannya kelah ketika lulus dari sekolah kebisaaan itu melekat dihati anak.

Dalam pelaksanaanya peran guru dalam mengajar, seperti mengajak anak untuk menggunakan mediamedia yang ada disekitar lingkungan sekolah, memberikan stimulus untuk memacu skill dan kreatifitas anak, dan melakukan pendekatan kepada anak yang mengalami kesulitan belajar. Ketiga, menyelingi pembelajaran sambil bernyanyi dan bermain. Keempat, memperhatikan efektifitas penggunaan media, efektifitas waktu untuk menghindari kejenuhan belajar anak-anak. Kelima, menfungsikan orang tua dalam pembelajaran skill tertentu. 
Disini peran ganda seorang guru untuk mendidik anak-anak membutuhkan perhatian ekstra selama didalam kelas, langkah-langkah yang dilakukan oleh guru seperti ini disiasati dengan bernyanyi bersama, bermain game, membaca doa-doa untuk menajamkan ingatan mereka, semuanya itu untuk mencairkan suasana kelas dan menghindarkan kejenuhan anak. Jika ini dikesampingkan tidak menutup kemungkinan akan akan terus memunculkan respon yang kurang positif lagi, terakhir anak akan merengek kepada bundanya dan mengajak pulang.

secara umum efektifitas dalam pelaksanaannya sepenuhnya bertumpu pada kemampuan guru dalam mengkondisikan kelas, dalam penguasaan materi serta penguasaan media pembelajarannya, baik dalam pengadaan maupun penggunaan. Peran sentral guru perlu mendapat dukungan dan apresiasi dari pihak lembaga dan wali murid, dalam rangka mensukseskan proses belajar di RA Dewi Masyitoh tersebut. Dari gambaran singkat tersebut maka bisa dilihat pada Gambar.2 model pelaksanaan skill :

\section{Gambar.2}

Model Pelaksanaan Pembelajaran Skill

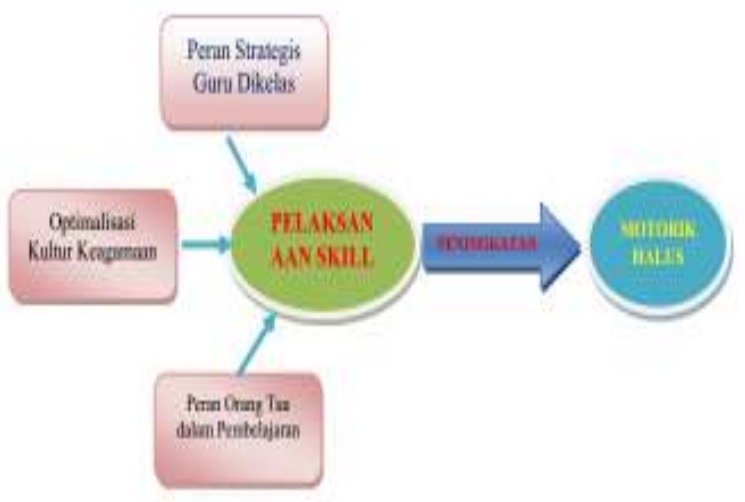

Evaluasi skilll melipat, menarik garis dan menuang biji dalam meningkatkan motorik halus anak usia dini. Evaluasi terhadap perencanan dan pelaksanaan pembelajaran skill melipat, menarik garis dan menuang biji di RA Dewi Masyitoh, pertama, Kontrol secara internal melalui pengawasan kepala sekolah terhadap kinerja pada guruguru, apakah sudah melaksanakan tugasnya dengan benar dan sesuai dengan job diskription pada perencanaan atau tidak. Kedua, dari sisi eksternal, kepuasan orang tua siswa merupakan keberhasilan pelaksanaan dan sebaliknya ketidak puasan orang tua merupakan indikator kegagalan sebuah kegiatan. Dari sini bisa dilihat sentralitas peran kepala sekolah bukan hanya sebagai kontroling, namun sebagai evaluator terhadap kinerja bawahannya.

Proses evaluasi yang dilakukan oleh guru sebagaimana evaluasi pada umumnya yaitu berbasis kelas dengan model tes dan non tes, disini guru mengacu pada pedoman yang ada. Sedangkan peranan orang tua dalam keikutsertaannya mengevaluasi perkembangan selama berada dikelas adalah dengan cara mereview, yaitu semacam teknik menanyakan pelajaran yang sudah didapat selama disekolah kepada anak yang dilakukannya ketika sudah pulang kerumah atau selama berada dirmah. Hal ini dilakukan untuk melihat dan mengasah daya ingat anak-anak dalam menangkap dan memahami pelajaran yang sudah didapatkannya.

Disini letak perbedaan model evaluasi yang dilakukan oleh kepala sekolah, para guru dan orang tua siswa. Perbedaan evaluasi tersebut sebenanrnya bermuara pada satu tujuan, yaitu untuk meningkatkan motorik halus 
anak, karena dunia anak yang sarat akan bermain, maka cara belajar yang efektif adalah dengan memberikan gambaran-gambaran tentang lingkungan dengan seluas-luasnya untuk memacu nalar dan kreatifitas yang dapat merangsang perkembangan motorik halus anak.kegiatan tersebut bisa dilihat pada Gambar.3 :

\section{Gambar.3}

Model Evaluasi Pembelajaran Skill

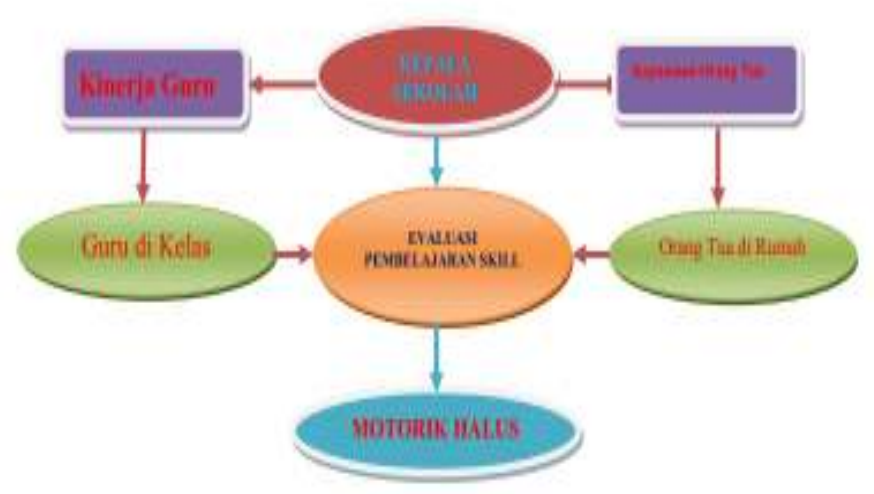

\section{SIMPULAN DAN SARAN}

\section{SIMPULAN}

Berdasarkan hasil penelitian, pengolahan dan analisa data yang telah penulis lakukan terkait dengan rumusan penelitian Implementasi Model Pembelajaran Learning By Playing Untuk Meningkatkan Motorik Halus Anak Usia Dini (Studikasus di RA Dewi Masyithoh Muslimat NU kecamatan Puger KAB. Jember) dan telah terurai, maka kesimpulan ini diantaranya:

Perenacaan skill, Secara umum perencanaan diantaranya, mengkroscek perencanaan kerja pada hari sebelumnya, membuat konsep untuk menindaklanjuti hasil belajar sebelumnya,menentukan permainan untuk menghidupkan pembelajaran, dan menentukan media pembelajaran.

Pelaksanaan skill, Pertama penerapan kultur keagamaan dalam proses pembelajaran Kedua, memaksimalkan peran dalam mengajar, seperti mengajak anak untuk menggunakan media-media yang ada disekitar lingkungan sekolah, memberikan stimulus untuk memacu skill dan kreatifitas anak, dan melakukan pendekatan kepada anak yang mengalami kesulitan belajar. Ketiga, menyelingi pembelajaran dengan bernyanyi dan bermain. Keempat, memperhatikan efektifitas penggunaan media dan efektifitas waktu, Kelima, menfungsikan orang tua dalam pembelajaran skill tertentu.

Evaluasi skill melipat,Evaluasi terhadap perencanan dan pelaksanaan pembelajaran skill dilakukan kepala sekolah pertama, Kontrol secara internal melalui pengawasan kinerja pada guru-guru. Kedua, dari sisi eksternal, kepuasan orang tua. Evaluasi yang dilakukan oleh guru maupun kepalasekolah sama-sama berpedoman pada kurikulum yang berlaku sebagai dasar utama perencanaan, pelaksanaan dan evaluasi.Untuk evaluasi orang tua tua kepada anak di rumah adalah dengan mereview pembelajaran yang sudah dididapatkan di sekolah.

\section{SARAN-SARAN}


Implementasi Model Pembelajaran Learning By Playing dalam Meningkatkan Motorik Halus Anak Usia Dini perlu dikembangkan dengan jalan mempertahankan budaya agama yang telah berkembang dan berusaha mengembangkannilai-nilai islam sebagai ruh bagi kegiatan pembelajaran anak-anak di sekolah, meningkatkan kemampuan manajeria ldalam pengembangan skill anak sehingga terjadipeningkatan kualitas secara berkesinambungan dan terus menerus serta guru diharapkan terus meningkatkan semangat dan komitmennya untuk mengembangkan kemampuan motorik anak. 


\section{PUSTAKA ACUAN}

Hurlock, 1978. Child Development. Sixth edition. Jakarta: Erlangga.

Kamtini \& Husni Wardi Tanjung. 2005. Bermain Melalui Gerak dan Lagu di TK. Jakarta: Departemen Pendidikan Nasional, Direktorat Jenderal Pendidikan Tinggi, Direktorat Pembinaan Pendidikan Tenaga Kependidikan dan Ketenagaan Perguruan Tinggi.

Moleong, Lexy J, 2006.Metodologi Penelitian Kualitatif, Bandung: PT. Remaja Rosdakarya

Ramli, 2005. Pendampingan Perkembangan Anak Usia Dini. Jakarta: Depdiknas.

Rosmala Dewi, 2005. Berbagai Masalah Anak Taman Kanak-kanak. Jakarta: Departemen Pendidikan Nasional, Direktorat Jenderal Pendidikan Tinggi, Direktorat Pembinaan Pendidikan Tenaga Kependidikan dan Ketenagaan Perguruan Tinggi

Santrock, 2007. Child Development. Eleventh edition Alih Bahasa: Mila Rachmawati \& Anna Kuswanti. Jakarta: Erlangga

Slamet Suyanto, 2005. Konsep dasar Pendidikan Anak Usia Dini. Jakarta: Departemen Pendidikan Nasional, Direktorat Jenderal Pendidikan Tinggi, Direktorat Pembinaan Pendidikan Tenaga Kependidikan dan Ketenagaan Perguruan Tinggi.

Sumantri, 2005. Model Pengembangan Keterampilan Motorik Anak Usia Dini. Jakarta: Departemen Pendidikan Nasional, Direktorat Jenderal Pendidikan Tinggi, Direktorat Pembinaan Pendidikan Tenaga Kependidikan dan Ketenagaan Perguruan Tinggi.

Tadkiroatun Musfiroh, 2005. Bermain Sambil Belajar dan Mengasah Kecerdasan. Jakarta: Departemen Pendidikan Nasional, Direktorat Jenderal Pendidikan Tinggi, Direktorat Pembinaan Pendidikan Tenaga Kependidikan dan Ketenagaan Perguruan Tinggi.

Yuliani Nurani dan Bambang Sujiono, 2010.Bermain Kreatif : Berbasis kecerdasan jamak,Jakarta : PT.Indeks. 